\title{
Analisis Kebangkrutan Perusahaan yang Terancam Delisting di Bursa Efek Indonesia
}

\author{
Putri Risnanti \\ Eny Kustiyah \\ Rochmi Widayanti
}

Manajemen, Universitas Islam Batik Surakarta, Indonesia

Korespondensi penulis: risna05putri@gmail.com

\begin{abstract}
Corporate bankruptcy can be seen from the performance of the company's financial statements. The purpose of this study is to find out how the performance of companies with suspension status in 2018 from January to October in the Indonesia Stock Exchange with 2016-2017 financial statement research. There are 13 companies that have suspension status in 2018 and still publish their financial statements between 2016-2017. The detection tool used in this study is the modified Altman Z-score Multiple Discriminant Analysis. With the results of this study there are six companies in healthy positions in two years between 2016-2017, five companies in bankruptcy positions, one company with the first year in a healthy position while the second year going bankrupt, and one company experiencing bankruptcy in the first year and grey area in the second year.
\end{abstract}

Keywords: Bankruptcy; Delisting; Suspension; Z-score.

Abstrak. Kebangkrutan perusahaan dapat dilihat dari kinerja laporan keuangan perusahaan. Tujuan penelitian ini adalah untuk mendeteksi bagaimana kinerja perusahaan yang bertatus suspensi pada tahun 2018 dari bulan januari hingga bulan oktober di Bursa Efek Indonesia dengan penelitian laporan keuangan tahun 2016-2017. Ada 13 perusahaan yang berstatus suspensi pada tahun 2018 dan masih mempublikasi laporan keuangannya antara tahun 2016-2017. Alat pendeteksi yang digunakan dalam penelitian ini yaitu multiple discriminant analysis Altman z-score modifikasi. Hasil penelitian ini menunjukkan enam perusahaan dalam posisi sehat dalam dua tahun antara tahun 20162017, lima perusahaan dalam posisi bangkrut, satu perusahaan dengan tahun pertama pada posisi sehat, sedangkan tahun kedua mengalami bangkrut, dan satu perusahaan lainnya mengalami posisi bangkrut di tahun pertama dan grey area di tahun kedua.

Kata Kunci: Kebangkrutan; Penghapusan pencatatan; Suspensi; Z-score. 


\section{LATAR BELAKANG}

Perkembangan perekonomian Indonesia berimplikasi pada intensitas persaingan antarperusahaan yang semakin meningkat. Semakin tingginya tingkat persaingan antarperusahaan menuntut perusahaan untuk giat melakukan inovasi, perbaikan kinerja, pengembangan sumber daya manusia, dan pengembangan produk agar unggul dalam persaingan dengan perusahaan lain (Bahri, 2015). Meningkatnya kegiatan bisnis menyebabkan perusahaan-perusahaan mencari sumber-sumber pembiayaan untuk membiayai kegiatan bisnisnya. Untuk memenuhi kebutuhan dana tersebut, perusahaan dapat menerbitkan surat berharga atau saham yang ditawarkan kepada invesror maupun masyarakat luas melalui pasar modal (Fitri, 2016). Bursa efek merupakan tempat transanksi produk-produk surat berharga di bawah pengawasan dan pembinaan pemerintah (Paradiba \& Nainggolan, 2015). Bursa efek diharapkan dapat mengakomodasi kebutuhan modal perusahaan yang terdaftar untuk mengembangkan perusahaan agar mencapai tujuan perusahaan (Gere, 2015).

Agar mampu bertahan dan berkembang dalam jangka waktu panjang, perusahaan didirikan dengan tujuan menghasilkan keuntungan (Permana, Ahmar, \& Djadang, 2017). Perusahaan go public yang terdaftar di bursa efek akan memanfaatkan pasar modal sebagai sarana mendapatkan sumber dana atau alternatif investasi untuk mendapatkan sumber pembiayaan (Puspitaningrum \& Purnamasari, 2016). Pada dasarnya, perusahaan memutuskan go public untuk memperoleh manfaat lebih, yaitu memperoleh modal dengan biaya yang relatif rendah, memenuhi kebutuhan likuiditas, serta peningkatan pendapatan dan laba (Lakhaye, 2014). Beberapa perusahaan yang beroperasi dalam jangka waktu tertentu terpaksa gagal memenuhi kewajibannya atau dilikuidasi, karena mengalami kesulitan keuangan (Permana et al., 2017). Jika perusahaan tidak mampu mengantisipasi dan mempersiapkan diri untuk menghadapi kesulitan keuangan, maka usahanya akan semakin meurun dan berujung pada kebangkrutan (Bahri, 2015).

Kebangkrutan dapat terjadi karena faktor internal maupun eksternal perusahaan. Jika perusahaan mengalami kebangkrutan, maka beberapa pihak akan mengalami kerugian, di antaranya pihak yang memiliki kepentingan kepada perusahaan seperti investor dan kreditor (Syafitri, 2013). Prediksi terhadap kebangkrutan dapat dilakukan melalui pengukuran laporan keuangan dan analisis rasio keuangan perusahaan untuk mengetahui posisi keuangan perusahaan (Bahri, 2015). Laporan keuangan juga digunakan sebagai informasi dari beberapa jenis informasi yang dipublikasikan di bursa efek dan melibatkan kondisi keuangan, kinerja, serta perubahan kondisi keuangan perusahaan (Paradiba \& Nainggolan, 2015). Jika perusahaan menghentikan publikasi laporan keuangan di bursa efek, perusahaan akan terkena suspensi atau penghentian sementara perdagangan saham perusahaan sebelum di delisting (Lakhaye, 2014).

Delisting merupakan tindakan penghapusan saham dari daftar saham yang tercatat di bursa efek, sehingga tidak dapat diperdagangkan di bursa disebut. Hal ini membuat para investor dan kreditor tidak dapat melihat kinerja laporan keuangan perusahaan (Lakhaye, 2014). Bursa Efek Indonesia (BEI) memberlakukan peraturan ketat terhadap perusahaan yang terdaftar (listing). Jika perusahaan tidak memenuhi persyaratan, maka ia akan terancam delisting (Permana et al., 2017). BEI selaku otoritas penyelenggara bursa saham di Indonesia berwenang mengeluarkan perusahaan yang telah terdaftar dari perdagangan di bursa saham, ketika perusahaan tersebut tidak mematuhi peraturan yang telah ditetapkan BEI (Lakhaye, 2014). 
Bursa Efek Indonesia selaku media untuk memperjualbelikan saham telah memberikan peringatan pada tahun 2018 berupa suspensi kepada 40 emiten antara bulan Januari hingga Oktober 2018. Dari total 40 emiten tersebut, 17 emiten sudah dicabut masa suspensinya, 20 emiten masih dalam masa suspensi, dua emiten dilakukan delisting dari BEI, dan satu emiten bergabung dengan emiten lain. Salah satu faktor yang mendasari BEI memberikan sanksi kepada emiten adalah harga saham yang naik secara drastis, sehingga pihak BEI dapat menghentikan sementara penjualan saham oleh emiten tersebut.

Faktor lain yang juga dapat menyebabkan emiten mendapatkan sanksi tersebut adalah emiten yang tidak mempublikasikan laporan keuangannya selama beberapa tahun, sehingga pihak investor tidak bisa melihat hasil kinerjanya. Pada umumnya, apabila suatu emiten tidak atau belum mempublikasikan laporan keuangan, emiten tersebut diindikasikan mengalami kendala keuangan atau financial distress. Berdasarkan hal tersebut, maka penelitian ini akan mengungkap apakah suatu perusahaan yang tidak atau belum mempublikasikan laporan keuangannya merupakan indikasi bahwa perusahaan tersebut sedang mengalami financial distress.

Berdasarkan latar belakang tersebut, maka rumusan masalah dalam penelitian ini adalah apakah perusahaan yang berada dalam masa suspensi karena mengalami penurunan kinerja dapat berpotensi mengalami kebangkrutan ataukah berada dalam grey area? Penelitian ini bertujuan untuk mengetahui kondisi kinerja perusahaan-perusahaan yang berada di dalam masa suspensi di Bursa Efek Indonesia (BEI) dengan menggunakan analisis kebangkrutan dan mendiskripsikan perusahaan yang berada dalam masa suspensi dapat berpotensi mengalami kebangkrutan atau pun berada dalam grey area.

\section{KAJIAN TEORITIS}

\section{Laporan Keuangan}

Hasil dari proses pembukuan akuntansi yang digunakan sebagai alat untuk mengomunikasikan aktifitas data keuangan perusahaan kepada pihak yang berkaitan terhadap perusahaan, yaitu pihak internal dan eksternal adalah laporan keuangan (Savitri, 2014). Ada pun tujuan penyusunan laporan keuangan adalah memberikan penjelasan jenis dan jumlah aktiva perusahaan, modal dan kewajiban perusahaan, jumlah dan jenis pendapatan yang diperoleh, dan aktifitas perubahan kinerja keuangan perusahaan (Fitri, 2016). Laporan keuangan yang lengkap terdiri atas neraca, laporan laba/rugi, laporan perubahan posisi keuangan, catatan, dan laporan lain beserta materi penjelasan yang menjadi bagian integral laporan keuangan, termasuk skedul dan informasi tambahan yang berkaitan dengan laporan keuangan (Bahri, 2015).

\section{Kebangkrutan}

Perusahaan yang mengalami kondisi kekurangan atau ketidakcukupan dana, sehingga perusahaan tersebut tidak lagi mampu untuk membayar kewajiban dan menyebabkan ia tidak bisa menjalankan atau melanjutkan usahanya disebut kondisi kebangkrutan. Kebangkrutan dapat mengakibatkan penutupan usaha perusahan atau likuidasi (Bahri, 2015). 


\section{Penyebab Kebangkrutan}

Ada tiga faktor penyebab terjadinya kebangkrutan. Pertama, faktor umum yang terdiri atas faktor ekonomi, sosial, teknologi, dan pemerintah. Kedua, faktor eksternal terdiri atas faktor pelanggan, pemasok, dan pesaing. Ketiga, faktor internal yaitu faktor yang disebabkan oleh perusahaan sendiri, seperti manajemen yang kurang tertata dengan baik, besarnya kredit yang diberikan kepada klien, dan lain-lain (Sembiring, 2016).

\section{Financial Distress}

Financial distress diartikan dengan persepsi luas yang terdiri atas beberapa kondisi, ketika perusahaan menghadapi kesulitan keuangan. Istilah umum yang biasa digunakan adalah kebangkrutan, kegagalan, ketidakmampuan melunasi hutang, dan default (Vestari \& Farida, 2017).

\section{Altman Z-Score}

Multiple discriminant analysis diterapkan sebagai alat untuk menganalisis kebangkrutan perusahaan oleh Altman pada tahun 1968 (Altman, 2007). Altman (2007) menyatakan bahwa untuk menilai analisis rasio sebagai teknik analitik, serangkaian rasio keuangan dan ekonomi dianalisis dalam konteks prediksi kebangkrutan dengan menggunakan metodologi statistik multidiskriminan. Namun, kasus tersebut hanya terbatas pada perusahaan manufaktur. Tahun 1995, Altman kembali mengembangkan model Z-score menjadi Z"'-score. Z"-score (Altman, Hartzell, \& Peck, 1995; Altman \& Hotchkiss, 2006, hal. 314) diperkenalkan untuk perusahaan di sektor non-manufaktur dan manufaktur atau perusahaan yang beroperasi di negara-negara berkembang (penelitian tahun 1995 menyelidiki sampel dari perusahaan-perusahaan di negara Meksiko) (Altman, Danovi, \& Falini, 2010):

$$
Z^{\prime \prime}=6.56 X_{1}+3.26 X_{2}+6.72 X_{3}+1.05 X_{4}
$$

\section{Suspensi}

Suspensi diartikan sebagai tindakan penghentian sementara perdagangan saham perusahaan tertentu oleh otoritas bursa efek karena suatu alasan (Safitri et al., 2018). Tindakan suspensi dilakukan otoritas bursa, apabila saham suatu perusahan mengalami lonjakan harga yang luar biasa, saham mengalami punurunan harga yang luar biasa, atau karena alasan kondisi lain yang mengharuskan otoritas bursa menghentikan sementara perdagangan saham tersebut (Safitri et al., 2018).

\section{Delisting}

Perusahaan yang tercatat sebagai perusahaan go public di Bursa Efek Indonesia, tidak selamanya berjalan dengan baik. Savitri (2014), perusahaan dituntut untuk memenuhi semua kewajibannya sebagai perusahaan listing. Apabila kewajiban tersebut tidak bisa dipenuhi, maka perusahaan dapat terancam delisting dari Bursa Efek Indonesia. Delisting bisa terjadi apabila (Savitri, 2014):

1. Dilakukan dengan cara paksa (forced delisting), yaitu emiten yang tidak lagi dapat memenuhi kriteria dan syarat pencatatan yang ditetapkan oleh Bursa Efek Indonesia.

2. Dilakukan dengan cara sukarela (voluntary delisting), yaitu emiten mengajukan permintaan untuk keluar dari bursa. 


\section{Rerangka Pemikiran}

Penelitian ini menggunakan data tahunan laporan keuangan perusahaan-perusahaan yang berada dalam masa suspensi pada bulan Januari-Oktober tahun 2018 yang dipublikasikan oleh masing-masing perusahaan di Bursa Efek Indonesia. Data tersebut dianalisis menggunakan analisis Financial Distress, yaitu Altman Z-score untuk mengetahui kondisi keuangan perusahaan, apakah dalam posisi sehat ataukah bangkrut. Selanjutnya, hasil analisis tersebut disimpulkan terkait bagaimana keadaan perusahaanperusahaan yang diteliti.

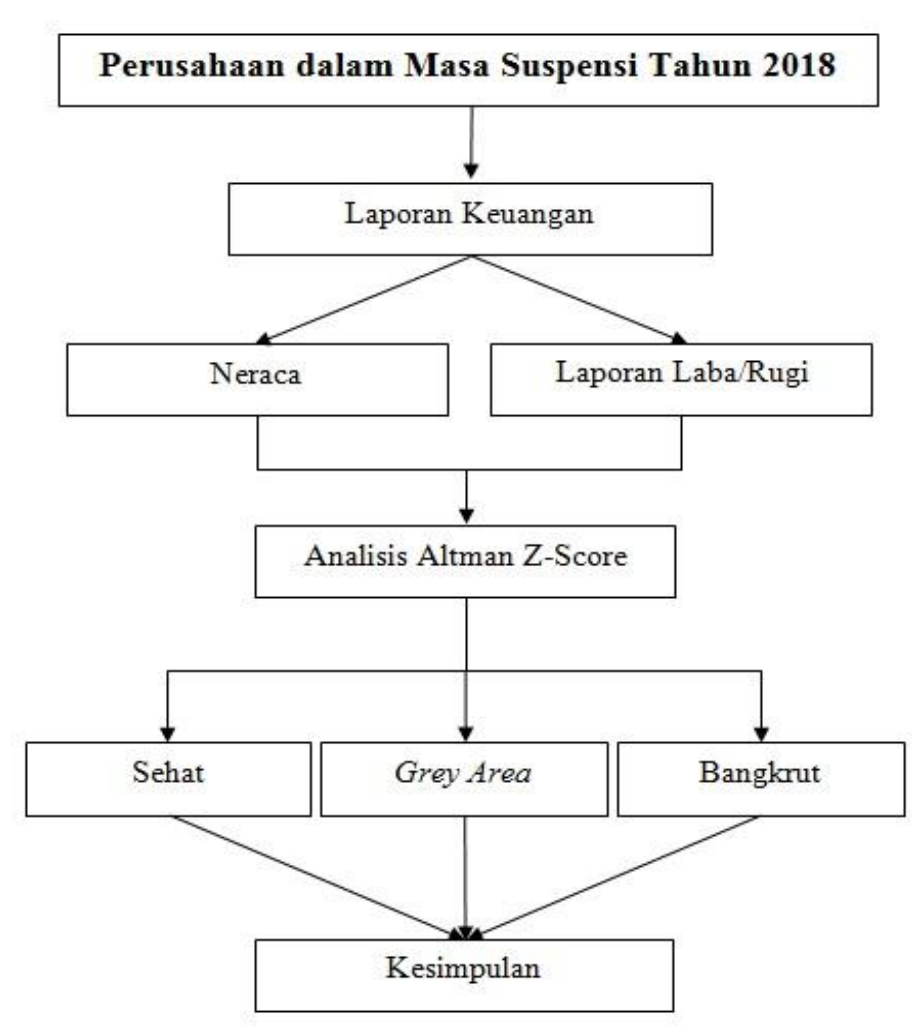

Sumber: Bahri (2015).

Gambar 1. Model Penelitian

\section{METODE PENELITIAN}

\section{Jenis Penelitian}

Jenis penelitian yang digunakan dalam penelitian ini adalah penelitian diskriptif. Penelitian diskriptif merupakan penelitian yang disusun dalam rangka untuk memberikan gambaran secara sistematis mengenai informasi ilmiah yang berasal dari subyek atau obyek penelitian. Inti dari penelitian diskriptif adalah penjelasan sistematis tentang fakta yang diperoleh pada saat penelitian dilakukan (Sanusi, 2011: 13).

\section{Obyek Penelitian}

Obyek penelitian ini adalah laporan keuangan tahunan perusahaan yang terdaftar di Bursa Efek Indonesia (BEI) periode tahun 2016-2017. 


\section{Populasi dan Sampel}

Populasi dalam penelitian ini adalah perusahaan-perusahaan yang terkena suspensi oleh Bursa Efek Indonesia pada tahun 2018 antara bulan Januari hingga Oktober, yaitu 40 perusahaan yang diberitakan dalam masa suspensi dari tanggal 10 Januari-30 Oktober 2018. Metode penentuan sampel yang digunakan dalam penelitian ini menggunakan non-probability sampling, yaitu purposive sampling dengan mendasarkan pada kriteria bahwa perusahaan-perusahaan yang masih berada dalam masa suspensi sampai dengan bulan Oktober 2018 dan belum dicabut masa suspensinya oleh pihak BEI, serta perusahan masih mempublikasikan laporan keuangannya dari tahun 2016-2017.

Berdasarkan kriteria tersebut, 20 perusahaan masih berada dalam masa suspensi hingga akhir bulan Oktober 2018. Dari 20 perusahaan tersebut, jumlah perusahaan yang masih mempublikasikan laporan keuangan antara tahun 2016-2017 adalah 13 perusahaan, sehingga jumlah inilah yang digunakan sebagai sampel. Ada pun perusahaan-perusahaan sampel tersebut adalah:

1. PT Indonesia Prima Property, Tbk. (OMRE)

2. PT Golden Energy Mines, Tbk. (GEMS)

3. PT Borneo Lumbung Energi \& Metal, Tbk. (BORN)

4. PT Bank of India Indonesia, Tbk. (BSWD)

5. PT Toba Pulp Lestari, Tbk. (INRU)

6. PT Alfa Energi Investama, Tbk. (FIRE)

7. PT Indo-Rama Synthetics, Tbk. (INDR)

8. PT Bara Jaya Internasional, Tbk. (ATPK)

9. PT Cakra Mineral, Tbk. $\quad$ (CKRA)

10. PT Tiga Pilar Sejahtera Food, Tbk. $\quad$ (AISA)

11. PT Intermedia Capital, Tbk. (MDIA)

12. PT Sekawan Intipratama, Tbk. $\quad$ (SIAP)

13. PT Akbar Indo Makmur Stimec, Tbk. $\quad$ (AIMS)

\section{Jenis dan Sumber Data}

Jenis data yang digunakan dalam penelitian ini adalah data kuantitatif berupa laporan keuangan perusahaan-perusahaan yang berada dalam masa suspensi di Bursa Efek Indonesia (BEI) periode tahun 2016 dan 2017, sedangkan sumber data yang digunakan adalah data sekunder yang bersumber dari publikasi laporan keuangan oleh BEI.

\section{Teknik Pengumpulan Data}

Teknik pengumpulan data dilakukan dengan cara observasi non-partisipan pada laporan keuangan yang dipublikasikan oleh perusahaan di Bursa Efek Indonesia (BEI) periode tahun 2016-2017. Observasi non-partisipan merupakan teknik pengumpulan data dengan cara pengamatan, yaitu peneliti tidak terlibat langsung dan hanya sebagai pengamat independen (Gupta \& Suartana, 2018).

\section{Definisi Operasional Variabel}

Definisi operasional variabel yang digunakan dalam penelitian ini mengacu pada analisis kebangkrutan model yang dimodifikasi atau Altman Z"-score dengan rumusan sebagai berikut:

$$
Z "=6,56 X_{1}+3,26 X_{2}+6,72 X_{3}+1,05 X_{4}
$$

Sumber: Altman et al. (2010). 
Keterangan:

$\mathrm{X}_{1}=$ Modal Kerja / Total Aktiva

$\mathrm{X}_{2}=$ Saldo Laba / Total Aktiva

$\mathrm{X}_{3}=$ Penghasilan Sebelum Bunga dan Pajak / Total Aktiva

$\mathrm{X}_{4}=$ Nilai Buku Ekuitas / Nilai Buku Hutang

\section{HASIL DAN PEMBAHASAN}

Berikut ini adalah perhitungan laporan keuangan 13 perusahaan sampel yang berstatus suspensi oleh Bursa Efek Indonesia dari tahun 2016-2017 dengan multiple discriminant analysis, yaitu Altman Z-score yang dimodifikasi.

\section{Perhitungan Variabel $x_{1}$}

Variabel $\mathrm{X}_{1}$ diperoleh dari modal kerja dibagi total aktiva, sedangkan modal kerja diperoleh dari aktiva lancar dikurangi hutang lancer (Tabel 1).

Tabel 1. Perhitungan Aktiva Lancar Dikurangi Hutang Lancar

\begin{tabular}{|c|c|c|c|c|c|c|c|}
\hline \multirow{2}{*}{$\begin{array}{r}\text { Kode } \\
\text { OMRE }\end{array}$} & \multirow{2}{*}{$\begin{array}{c}\text { Tahun } \\
2016\end{array}$} & Aktiva Lancar & \multicolumn{2}{|r|}{ Hutang lancar } & \multicolumn{2}{|r|}{ Modal Kerja } & \multirow{2}{*}{$\begin{array}{c}\text { Keadaan } \\
\text { Modal } \\
\text { Kerja } \\
\end{array}$} \\
\hline & & 213.759 .695 & $\mathrm{Rp}$ & 52.725 .343 & $\mathrm{Rp}$ & 161.034 .351 & \\
\hline & 2017 & 212.689 .433 & $\mathrm{Rp}$ & 121.138 .360 & $\mathrm{Rp}$ & 91.551 .073 & $(43 \%)$ \\
\hline \multirow[t]{2}{*}{ GEMS } & 2016 & $\operatorname{Rp} 2.741 .989 .703$ & $\mathrm{Rp}$ & 726.495 .056 & $\mathrm{Rp}$ & 2.015 .494 .646 & \\
\hline & 2017 & Rp 5.616.988.041 & $\mathrm{Rp}$ & 3.338 .837 .545 & $\mathrm{Rp}$ & 2.278 .150 .496 & $13 \%$ \\
\hline \multirow[t]{2}{*}{ BORN } & 2016 & $\operatorname{Rp} 3.537 .843 .686$ & $\mathrm{Rp}$ & 1.571 .916 .973 & $\mathrm{Rp}$ & 8.034.073.287) & \\
\hline & 2017 & Rp 4.666.892.629 & $\mathrm{Rp}$ & 1.955.523.269 & $\mathrm{Rp}$ & 7.288.630.640) & $(9 \%)$ \\
\hline \multirow[t]{2}{*}{ BSWD } & 2016 & $\operatorname{Rp} 4.188 .821 .058$ & $\mathrm{Rp}$ & 3.337 .355 .587 & $\mathrm{Rp}$ & 851.465 .470 & \\
\hline & 2017 & Rp 3.828.707.636 & $\mathrm{Rp}$ & 3.175 .399 .451 & $\mathrm{Rp}$ & 653.308 .185 & $(23 \%)$ \\
\hline \multirow[t]{2}{*}{ INRU } & 2016 & $\begin{array}{ll}\mathrm{Rp} & 662.973 .360\end{array}$ & $\mathrm{Rp}$ & 905.222 .444 & $\mathrm{Rp}$ & $(242.249 .080)$ & \\
\hline & 2017 & 558.458 .538 & $\mathrm{Rp}$ & 373.515 .444 & $\mathrm{Rp}$ & 184.943 .094 & $(176 \%)$ \\
\hline \multirow[t]{2}{*}{ FIRE } & 2016 & 88.855 .470 & $\mathrm{Rp}$ & 84.332 .825 & $\mathrm{Rp}$ & 4.522 .645 & \\
\hline & 2017 & 210.136 .437 & $\mathrm{Rp}$ & 78.581 .190 & $\mathrm{Rp}$ & 131.555 .247 & $2809 \%$ \\
\hline \multirow[t]{2}{*}{ INDR } & 2016 & Rp 3.925.998.574 & $\mathrm{Rp}$ & 3.608 .896 .685 & $\mathrm{Rp}$ & 317.101 .889 & \\
\hline & 2017 & Rp 3.785.515.987 & $\mathrm{Rp}$ & 3.634.109.466 & $\mathrm{Rp}$ & 151.406 .521 & $(52 \%)$ \\
\hline \multirow[t]{2}{*}{ ATPK } & 2016 & $\begin{array}{ll}\mathrm{Rp} & 158.680 .482\end{array}$ & $\mathrm{Rp}$ & 230.620 .703 & $\mathrm{Rp}$ & $(71.940 .221)$ & \\
\hline & 2017 & 42.506 .637 & $\mathrm{Rp}$ & 217.211 .363 & $\mathrm{Rp}$ & $(174.704 .726)$ & $143 \%$ \\
\hline \multirow[t]{2}{*}{ CKRA } & 2016 & 236.531 .696 & $\mathrm{Rp}$ & 18.700 .045 & $\mathrm{Rp}$ & 217.831 .651 & \\
\hline & 2017 & $\mathrm{Rp} \quad 569.197 .623$ & $\mathrm{Rp}$ & 12.075 .307 & $\mathrm{Rp}$ & 557.122 .316 & $156 \%$ \\
\hline \multirow[t]{2}{*}{ AISA } & 2016 & Rp 5.949.164.000 & $\mathrm{Rp}$ & 2.504 .330 .000 & $\mathrm{Rp}$ & 3.444 .834 .000 & \\
\hline & 2017 & Rp 4.536.882.000 & $\mathrm{Rp}$ & 3.902 .708 .000 & $\mathrm{Rp}$ & 634.174.722 & $(88 \%)$ \\
\hline \multirow[t]{2}{*}{ MDIA } & 2016 & $\operatorname{Rp} 2.131 .976 .467$ & $\mathrm{Rp}$ & 560.843 .745 & $\mathrm{Rp}$ & 1.571 .132 .722 & \\
\hline & 2017 & $\mathrm{Rp} 4.434 .320 .177$ & $\mathrm{Rp}$ & 862.478 .791 & $\mathrm{Rp}$ & 3.571 .841 .386 & $127 \%$ \\
\hline \multirow[t]{2}{*}{ SIAP } & 2016 & $\begin{array}{ll}\mathrm{Rp} & 10.386 .996\end{array}$ & $\mathrm{Rp}$ & 560.843 .745 & $\mathrm{Rp}$ & $(23.533 .545)$ & \\
\hline & 2017 & 7.821 .430 & $\mathrm{Rp}$ & 862.478 .791 & $\mathrm{Rp}$ & $(33.163 .426)$ & $41 \%$ \\
\hline \multirow[t]{2}{*}{ AIMS } & 2016 & 17.009 .196 & $\mathrm{Rp}$ & 361.920 & $\mathrm{Rp}$ & 16.647 .277 & \\
\hline & 2017 & 15.100 .639 & $\mathrm{Rp}$ & 127.732 & $\mathrm{Rp}$ & 14.972 .906 & $(10 \%)$ \\
\hline
\end{tabular}

Sumber: Data diolah (2019).

Berdasarkan Tabel 1, modal kerja di enam perusahaan terdiri atas enam perusahaan sampel dari tahun 2016-2017 mengalami penurunan, yaitu PT Indonesia Prima Property, Tbk.; PT Borneo Lumbung Energi \& Metal, Tbk.; PT Bank of India Indonesia, Tbk.; PT Indo-Rama Synthetics, Tbk.; PT Tiga Pilar Sejahtera Food, Tbk.; 
dan PT Akbar Indo Makmur Stimec, Tbk., sedangkan tujuh perusahaan lainnya mengalami peningkatan modal kerja. Perusahaan yang mengalami peningkatan modal kerja adalah PT Golden Energy Mines, Tbk.; PT Toba Pulp Lestari, Tbk.; PT Alfa Energi Investama, Tbk.; PT Bara Jaya Internasional, Tbk.; PT Cakra Mineral, Tbk.; PT Intermedia Capital, Tbk.; dan PT Sekawan Intipratama, Tbk.

Tabel 2. Perhitungan Modal Kerja Dibagi Total Aktiva

\begin{tabular}{|c|c|c|c|c|c|c|c|}
\hline \multirow{3}{*}{$\frac{\text { Kode }}{\text { OMRE }}$} & \multirow{2}{*}{$\begin{array}{c}\text { Tahun } \\
2016\end{array}$} & \multicolumn{2}{|r|}{ Modal Kerja } & \multicolumn{2}{|r|}{ Total Aktiva } & \multirow{2}{*}{$\frac{\mathbf{X}_{\mathbf{1}}}{0,0378}$} & \multirow[t]{2}{*}{$\begin{array}{c}\text { Keadaan } \\
\text { Total Aktiva }\end{array}$} \\
\hline & & $\mathrm{Rp}$ & 161.034 .351 & $\mathrm{Rp}$ & 4.264 .983 .383 & & \\
\hline & 2017 & $\mathrm{Rp}$ & 91.551 .073 & $\mathrm{Rp}$ & 4.242.934.700 & 0,0216 & $(1 \%)$ \\
\hline \multirow[t]{2}{*}{ GEMS } & 2016 & $\mathrm{Rp}$ & 2.015 .494 .646 & $\mathrm{Rp}$ & 5.090 .991 .600 & 0,3959 & \\
\hline & 2017 & $\mathrm{Rp}$ & 2.278.150.496 & $\mathrm{Rp}$ & 7.996.136.398 & 0,2849 & $57 \%$ \\
\hline \multirow[t]{2}{*}{ BORN } & 2016 & $\mathrm{Rp}$ & $(8.034 .073 .287)$ & $\mathrm{Rp}$ & 12.552 .542 .475 & $(0,6400)$ & \\
\hline & 2017 & $\mathrm{Rp}$ & $(7.288 .630 .640)$ & $\mathrm{Rp}$ & 13.394.121.590 & $(0,5442)$ & $7 \%$ \\
\hline \multirow[t]{2}{*}{ BSWD } & 2016 & $\mathrm{Rp}$ & 851.465 .470 & & 4.306 .073 .550 & 0,1977 & \\
\hline & 2017 & $\mathrm{Rp}$ & 653.308 .185 & $\mathrm{Rp}$ & 4.487.328.862 & 0,1456 & $4 \%$ \\
\hline \multirow[t]{2}{*}{ INRU } & 2016 & $\mathrm{Rp}$ & $(242.249 .080)$ & $\mathrm{Rp}$ & 4.575 .489 .440 & $(0,0529)$ & \\
\hline & 2017 & $\mathrm{Rp}$ & 184.943 .094 & $\mathrm{Rp}$ & 4.571.576.070 & 0,0405 & stabil \\
\hline \multirow[t]{2}{*}{ FIRE } & 2016 & $\mathrm{Rp}$ & 4.522 .645 & $\mathrm{Rp}$ & 333.255 .214 & 0,0136 & \\
\hline & 2017 & $\mathrm{Rp}$ & 131.555 .247 & $\mathrm{Rp}$ & 457.422 .863 & 0,2876 & $37 \%$ \\
\hline \multirow[t]{2}{*}{ INDR } & 2016 & $\mathrm{Rp}$ & 317.101 .889 & $\mathrm{Rp}$ & 11.371 .481 .235 & 0,02789 & \\
\hline & 2017 & $\mathrm{Rp}$ & 151.406 .521 & $\mathrm{Rp}$ & 10.835.068.914 & 0,01397 & $(5 \%)$ \\
\hline \multirow[t]{2}{*}{ ATPK } & 2016 & $\mathrm{Rp}$ & $(71.940 .221)$ & $\mathrm{Rp}$ & 1.585 .848 .621 & $(0,0454)$ & \\
\hline & 2017 & $\mathrm{Rp}$ & $(174.702 .726)$ & $\mathrm{Rp}$ & 1.004 .852 .063 & $(0,1739)$ & $(37 \%)$ \\
\hline \multirow[t]{2}{*}{ CKRA } & 2016 & $\mathrm{Rp}$ & 217.831 .651 & $\mathrm{Rp}$ & 905.470 .549 & 0,2406 & \\
\hline & 2017 & $\mathrm{Rp}$ & 557.122 .316 & $\mathrm{Rp}$ & 569.459 .087 & 0,9783 & $(37 \%)$ \\
\hline \multirow[t]{2}{*}{ AISA } & 2016 & $\mathrm{Rp}$ & 3.444 .834 .000 & $\mathrm{Rp}$ & 9.254 .539 .000 & 0,3722 & \\
\hline & 2017 & $\mathrm{Rp}$ & 634.174 .000 & $\mathrm{Rp}$ & 8.724 .734 .000 & 0,0727 & $(6 \%)$ \\
\hline \multirow[t]{2}{*}{ MDIA } & 2016 & $\mathrm{Rp}$ & 1.571 .132 .722 & $\mathrm{Rp}$ & 2.973 .235 .205 & 0,5284 & \\
\hline & 2017 & $\mathrm{Rp}$ & 3.571 .841 .386 & $\mathrm{Rp}$ & 5.149.249.808 & 0,6937 & $73 \%$ \\
\hline \multirow[t]{2}{*}{ SIAP } & 2016 & $\mathrm{Rp}$ & $(23.533 .545)$ & $\mathrm{Rp}$ & 228.709 .028 & $(0,1029)$ & \\
\hline & 2017 & $\mathrm{Rp}$ & $(33.163 .426)$ & $\mathrm{Rp}$ & 227.225 .263 & $(0,1459)$ & $(1 \%)$ \\
\hline \multirow[t]{2}{*}{ AIMS } & 2016 & $\mathrm{Rp}$ & 16.647 .277 & $\mathrm{Rp}$ & 17.009 .196 & 0,9787 & \\
\hline & 2017 & $\mathrm{Rp}$ & 14.972 .906 & $\mathrm{Rp}$ & 15.100 .639 & 0,9915 & $(11 \%)$ \\
\hline
\end{tabular}

Sumber: Data diolah (2019).

Tabel 2 menunjukkan data total aktiva pada 13 perusahaan. Data tersebut menunjukkan tujuh perusahaan dari 13 perusahaan sampel yang diteliti mengalami penurunan aktiva, yaitu PT Indonesia Prima Property, Tbk.; PT Indo-Rama Synthetics, Tbk.; PT Bara Jaya Internasional, Tbk.; PT Cakra Mineral, Tbk.; PT Tiga Pilar Sejahtera Food, Tbk.; PT Sekawan Intipratama, Tbk.; dan PT Akbar Indo Makmur Stimec, Tbk. Perusahaan yang mengalami peningkatan total aktiva adalah lima perusahaan, yaitu PT Golden Energy Mines, Tbk.; PT Borneo Lumbung Energi \& Metal, Tbk.; PT Bank of India Indonesia, Tbk.; PT Alfa Energi Investama, Tbk.; PT Intermedia Capital, Tbk., sedangkan satu perusahaan yaitu PT Toba Pulp Lestari, Tbk. memiliki total aktiva yang stabil.

\section{Perhitungan Variabel $x_{2}$}

Variabel $\mathrm{X}_{2}$ diperoleh dari saldo laba dibagi total aktiva. Tabel 3 menunjukkan keadaan saldo laba dengan hasil perolehan pada dua perusahaan yang mengalami 
penurunan saldo laba, yaitu PT Indonesia Prima Property, Tbk. dan PT Tiga Pilar Sejahtera Food, Tbk., sedangkan untuk saldo laba yang keadaannya stabil adalah lima perusahaan, yaitu PT Borneo Lumbung Energi \& Metal, Tbk.; PT Bank of India Indonesia, Tbk.; PT Toba Pulp Lestari, Tbk.; PT Cakra Mineral, Tbk. dan PT Akbar Indo Makmur Stimec, Tbk. Enam perusahaan lainnya berada dalam keadaan saldo laba meningkat, yaitu PT Golden Energy Mines, Tbk.; PT Alfa Energi Investama, Tbk.; PT Indo-Rama Synthetics, Tbk.; PT Bara Jaya Internasional, Tbk.; PT Intermedia Capital, Tbk.; dan PT Sekawan Intipratama, Tbk.

Tabel 3. Perhitungan Saldo Laba Dibagi Total Aktiva

\begin{tabular}{|c|c|c|c|c|c|c|c|}
\hline Kode & Tahun & & Saldo Laba & & Total Aktiva & $\mathbf{X}_{2}$ & $\begin{array}{c}\text { Keadaan } \\
\text { Saldo Laba }\end{array}$ \\
\hline \multirow[t]{2}{*}{ OMRE } & 2016 & $\mathrm{Rp}$ & 2.946 .957 .190 & $\mathrm{Rp}$ & 4.264 .983 .383 & 0,6910 & \\
\hline & 2017 & $\mathrm{Rp}$ & 2.879 .168 .169 & $\mathrm{Rp}$ & 4.242 .934 .700 & 0,6786 & $(2 \%)$ \\
\hline \multirow[t]{2}{*}{ GEMS } & 2016 & $\mathrm{Rp}$ & 5.955 .289 & $\mathrm{Rp}$ & 5.090 .991 .600 & 0,0012 & \\
\hline & 2017 & $\mathrm{Rp}$ & 6.991 .559 & $\mathrm{Rp}$ & 7.996.136.398 & 0,0009 & $17 \%$ \\
\hline \multirow[t]{2}{*}{ BORN } & 2016 & $\mathrm{Rp}$ & 1.861 .313 .979 & $\mathrm{Rp}$ & 12.552 .542 .475 & 0,1483 & \\
\hline & 2017 & $\mathrm{Rp}$ & 1.869 .874 .918 & $\mathrm{Rp}$ & 13.394 .121 .590 & 0,1396 & stabil \\
\hline \multirow[t]{2}{*}{ BSWD } & 2016 & $\mathrm{Rp}$ & 20.000 .000 & $\mathrm{Rp}$ & 4.306 .073 .550 & 0,0046 & \\
\hline & 2017 & $\mathrm{Rp}$ & 20.000 .000 & $\mathrm{Rp}$ & 4.487.328.862 & 0,0045 & stabil \\
\hline \multirow[t]{2}{*}{ INRU } & 2016 & $\mathrm{Rp}$ & $(7.110 .389 .960)$ & $\mathrm{Rp}$ & 4.575 .489 .440 & $(1,5540)$ & \\
\hline & 2017 & $\mathrm{Rp}$ & (7.137.934.032) & $\mathrm{Rp}$ & 4.571.576.070 & $(1,5614)$ & stabil \\
\hline \multirow[t]{2}{*}{ FIRE } & 2016 & $\mathrm{Rp}$ & $(14.995 .638)$ & $\mathrm{Rp}$ & 333.255 .214 & $(0,0450)$ & \\
\hline & 2017 & $\mathrm{Rp}$ & (16.118.918) & $\mathrm{Rp}$ & 457.422 .863 & $(0,0352)$ & $7 \%$ \\
\hline \multirow[t]{2}{*}{ INDR } & 2016 & $\mathrm{Rp}$ & 235.563 & $\mathrm{Rp}$ & 11.371 .481 .235 & 0,00002 & \\
\hline & 2017 & $\mathrm{Rp}$ & 250.188 & $\mathrm{Rp}$ & 10.835 .068 .914 & 0,00002 & $7 \%$ \\
\hline \multirow[t]{2}{*}{ ATPK } & 2016 & $\mathrm{Rp}$ & $(584.943 .286)$ & $\mathrm{Rp}$ & 1.585 .848 .621 & $(0,3689)$ & \\
\hline & 2017 & $\mathrm{Rp}$ & $(921.381 .833)$ & $\mathrm{Rp}$ & 1.004 .852 .063 & $(0,9169)$ & $58 \%$ \\
\hline \multirow[t]{2}{*}{ CKRA } & 2016 & $\mathrm{Rp}$ & 100.000 & $\mathrm{Rp}$ & 905.470 .549 & 0,0001 & \\
\hline & 2017 & $\mathrm{Rp}$ & 100.000 & $\mathrm{Rp}$ & 569.459 .087 & 0,0002 & stabil \\
\hline \multirow[t]{2}{*}{ AISA } & 2016 & $\mathrm{Rp}$ & 1.796 .408 .000 & $\mathrm{Rp}$ & 9.254 .539 .000 & 0,1941 & \\
\hline & 2017 & $\mathrm{Rp}$ & 1.231 .304 .000 & $\mathrm{Rp}$ & 8.724 .734 .000 & 0,1411 & $(31 \%)$ \\
\hline \multirow[t]{2}{*}{ MDIA } & 2016 & $\mathrm{Rp}$ & 15.950 .971 & $\mathrm{Rp}$ & 2.973 .235 .205 & 0,0054 & \\
\hline & 2017 & $\mathrm{Rp}$ & 20.950 .971 & $\mathrm{Rp}$ & 5.149.249.808 & 0,0041 & $31 \%$ \\
\hline \multirow[t]{2}{*}{ SIAP } & 2016 & $\mathrm{Rp}$ & $(95.698 .879)$ & $\mathrm{Rp}$ & 228.709 .028 & $(0,4184)$ & \\
\hline & 2017 & $\mathrm{Rp}$ & $(106.344 .506)$ & $\mathrm{Rp}$ & 227.225 .263 & $(0,4680)$ & $11 \%$ \\
\hline \multirow[t]{2}{*}{ AIMS } & 2016 & $\mathrm{Rp}$ & 146.324 & $\mathrm{Rp}$ & 17.009 .196 & 0,0086 & \\
\hline & 2017 & $\mathrm{Rp}$ & 146.324 & $\mathrm{Rp}$ & 15.100 .639 & 0,0097 & stabil \\
\hline
\end{tabular}

Sumber: Data diolah (2019).

\section{Perhitungan Variabel $x_{3}$}

Variabel $\mathrm{X}_{3}$ diperoleh dari penghasilan sebelum bunga dan pajak (EBIT) dibagi total aktiva. Keadaan EBIT pada ke-13 perusahaan dapat dilihat pada Tabel 4 dengan hasil perolehan sebagai berikut: sembilan perusahaan mengalami penurunan laba sebelum bunga dan pajak, yaitu PT Indonesia Prima Property, Tbk.; PT Borneo Lumbung Energi \& Metal, Tbk.; PT Bank of India Indonesia, Tbk.; PT Toba Pulp Lestari, Tbk.; PT Alfa Energi Investama, Tbk.; PT Tiga Pilar Sejahtera Food, Tbk.; PT Intermedia Capital, Tbk.; PT Sekawan Intipratama, Tbk.; dan PT Akbar Indo Makmur Stimec, Tbk. Perusahaan dengan keadaan EBIT yang meningkat berjumlah empat perusahaan, yaitu PT Golden Energy Mines, Tbk.; PT Indo-Rama Synthetics, Tbk.; PT Bara Jaya Internasional, Tbk.; dan PT Cakra Mineral, Tbk. 
Tabel 4. Perhitungan Laba Sebelum Pajak dan Bunga Dikurangi Total Aktiva

\begin{tabular}{|c|c|c|c|c|c|c|c|}
\hline Kode & Tahun & & EBIT & & Total Aktiva & $\mathbf{X}_{3}$ & $\begin{array}{c}\text { Keadaan } \\
\text { EBIT }\end{array}$ \\
\hline \multirow[t]{2}{*}{ OMRE } & 2016 & $\mathrm{Rp}$ & 316.304 .514 & $\mathrm{Rp}$ & 4.264 .983 .383 & 0,0742 & \\
\hline & 2017 & $\mathrm{Rp}$ & $(67.934 .435)$ & $\mathrm{Rp}$ & 4.242 .934 .700 & $(0,0160)$ & $(121 \%)$ \\
\hline \multirow[t]{2}{*}{ GEMS } & 2016 & $\mathrm{Rp}$ & 733.782 .654 & $\mathrm{Rp}$ & 5.090 .991 .600 & 0,1295 & \\
\hline & 2017 & $\mathrm{Rp}$ & 2.333 .678 .709 & $\mathrm{Rp}$ & 7.996.136.398 & 0,2833 & $218 \%$ \\
\hline \multirow[t]{2}{*}{ BORN } & 2016 & $\mathrm{Rp}$ & 2.481 .146 .499 & $\mathrm{Rp}$ & 12.552 .542 .475 & 0,1977 & \\
\hline & 2017 & $\mathrm{Rp}$ & 725.745 .505 & $\mathrm{Rp}$ & 13.394.121.590 & 0,0542 & $(71 \%)$ \\
\hline \multirow[t]{2}{*}{ BSWD } & 2016 & $\mathrm{Rp}$ & $(822.847 .777)$ & $\mathrm{Rp}$ & 4.306 .073 .550 & $(0,1911)$ & \\
\hline & 2017 & $\mathrm{Rp}$ & $(328.333 .708)$ & $\mathrm{Rp}$ & 4.487.328.862 & $(0,0732)$ & $(60 \%)$ \\
\hline \multirow[t]{2}{*}{ INRU } & 2016 & $\mathrm{Rp}$ & $(172.840 .560)$ & $\mathrm{Rp}$ & 4.575 .489 .440 & $(0,0529)$ & \\
\hline & 2017 & $\mathrm{Rp}$ & 25.893.304 & $\mathrm{Rp}$ & 4.571 .576 .070 & 0,0057 & $(115 \%)$ \\
\hline \multirow[t]{2}{*}{ FIRE } & 2016 & $\mathrm{Rp}$ & 18.709 .528 & $\mathrm{Rp}$ & 333.255 .214 & 0,0248 & \\
\hline & 2017 & $\mathrm{Rp}$ & 6.632 .910 & $\mathrm{Rp}$ & 457.422 .863 & 0,0036 & $(65 \%)$ \\
\hline \multirow[t]{2}{*}{ INDR } & 2016 & $\mathrm{Rp}$ & 85.771 .191 & $\mathrm{Rp}$ & 11.371 .481 .235 & 0,00754 & \\
\hline & 2017 & $\mathrm{Rp}$ & 160.877 .538 & $\mathrm{Rp}$ & 10.835 .068 .914 & 0,01485 & $88 \%$ \\
\hline \multirow[t]{2}{*}{ ATPK } & 2016 & $\mathrm{Rp}$ & (292.369.443) & $\mathrm{Rp}$ & 1.585 .848 .621 & $(0,1844)$ & \\
\hline & 2017 & $\mathrm{Rp}$ & $(311.025 .122)$ & $\mathrm{Rp}$ & 1.004 .852 .063 & $(0,3095)$ & $6 \%$ \\
\hline \multirow[t]{2}{*}{ CKRA } & 2016 & $\mathrm{Rp}$ & $(54.317 .477)$ & $\mathrm{Rp}$ & 905.470 .549 & $(0,0600)$ & \\
\hline & 2017 & $\mathrm{Rp}$ & $(260.062 .553)$ & $\mathrm{Rp}$ & 569.459 .087 & $(0,4567)$ & $379 \%$ \\
\hline \multirow[t]{2}{*}{ AISA } & 2016 & $\mathrm{Rp}$ & 898.431 .000 & $\mathrm{Rp}$ & 9.254 .539 .000 & 0,0971 & \\
\hline & 2017 & $\mathrm{Rp}$ & $(967.484 .000)$ & $\mathrm{Rp}$ & 8.724 .734 .000 & $(0,1109)$ & $(208 \%)$ \\
\hline \multirow[t]{2}{*}{ MDIA } & 2016 & $\mathrm{Rp}$ & 777.487 .304 & $\mathrm{Rp}$ & 2.973 .235 .205 & 0,2615 & \\
\hline & 2017 & $\mathrm{Rp}$ & 640.212 .360 & $\mathrm{Rp}$ & 5.149.249.808 & 0,1243 & $(18 \%)$ \\
\hline \multirow[t]{2}{*}{ SIAP } & 2016 & $\mathrm{Rp}$ & $(24.982 .843)$ & $\mathrm{Rp}$ & 228.709 .028 & $(0,1092)$ & \\
\hline & 2017 & $\mathrm{Rp}$ & $(11.548 .785)$ & $\mathrm{Rp}$ & 227.225 .263 & $(0,0508)$ & $(54 \%)$ \\
\hline \multirow[t]{2}{*}{ AIMS } & 2016 & $\mathrm{Rp}$ & $(2.216 .367)$ & $\mathrm{Rp}$ & 17.009 .196 & $(0,1303)$ & \\
\hline & 2017 & $\mathrm{Rp}$ & $(1.587 .692)$ & $\mathrm{Rp}$ & 15.100 .639 & $(0,1051)$ & $(28 \%)$ \\
\hline
\end{tabular}

Sumber: Data diolah (2019).

\section{Perhitungan Variabel $x_{4}$}

Variabel $\mathrm{X}_{4}$ diperoleh dari nilai buku ekuitas dibagi nilai buku hutang. Tabel 5 menunjukkan perolehan dan keadaan total hutang pada 13 perusahaan sampel. Enam perusahaan mengalami penurunan total hutang, yaitu PT Toba Pulp Lestari, Tbk.; PT Alfa Energi Investama, Tbk.; PT Indo-Rama Synthetics, Tbk.; PT Bara Jaya Internasional, Tbk.; PT Cakra Mineral, Tbk.; dan PT Akbar Indo Makmur Stimec, Tbk. Tujuh perusahaan lainnya mengalami peningkatan total hutang, yaitu PT Indonesia Prima Property, Tbk.; PT Golden Energy Mines, Tbk.; PT Borneo Lumbung Energi \& Metal, Tbk.; PT Bank of India Indonesia, Tbk.; PT Tiga Pilar Sejahtera Food, Tbk.; PT Intermedia Capital, Tbk.; dan PT Sekawan Intipratama, Tbk.

\section{Hasil Perhitungan Z"}

Z" diperoleh dari penjumlahan hasil perhitungan semua variabel $\mathrm{X}$, yaitu $\mathrm{X}_{1}, \mathrm{X}_{2}$, $\mathrm{X}_{3}$, dan $\mathrm{X}_{4}$, sehingga menghasilkan nilai Z”. Dari perhitungan hasil inilah, kriteria setiap perusahaan dapat diperoleh. Tabel 6 menunjukkan hasil perhitungan Altman Z-score yang dimodifikasi untuk periode tahun 2016-2017. Hasil tersebut mengindikasikan bahwa dari 13 perusahaan sampel yang diteliti, terdapat tujuh perusahaan dengan posisi sehat, yaitu enam perusahaan dalam keadaan sehat pada dua periode antara tahun 20162017 di antaranya adalah PT Indonesia Prima Property, Tbk. dengan nilai Z" berada di atas kategori nilai indikator, meskipun dengan hasil salah satu variabelnya negatif yaitu 
variabel $\mathrm{X}_{3}$ di tahun 2017, karena EBIT pada tahun 2017 nilainya negatif, dan juga total aktiva menurun serta total hutang meningkat.

Tabel 5. Perhitungan Aktiva Lancar Dikurangi Hutang Lancar

\begin{tabular}{|c|c|c|c|c|c|c|}
\hline Kode & Tahun & Nilai Buku Ekuitas & & Total Hutang & $\mathrm{X}_{4}$ & $\begin{array}{c}\text { Keadaan } \\
\text { Total Hutang }\end{array}$ \\
\hline \multirow[t]{2}{*}{ OMRE } & 2016 & 745.000 .000 & $\mathrm{Rp}$ & 146.961 .455 & 5,0694 & \\
\hline & 2017 & 745.000 .000 & $\mathrm{Rp}$ & 228.898 .177 & 3,2547 & $56 \%$ \\
\hline \multirow[t]{2}{*}{ GEMS } & 2016 & 877.089 .154 & $\mathrm{Rp}$ & 1.519 .887 .713 & 0,5771 & \\
\hline & 2017 & 881.123 .244 & $\mathrm{Rp}$ & 4.038.918.739 & 0,2182 & $166 \%$ \\
\hline \multirow[t]{2}{*}{ BORN } & 2016 & $\operatorname{Rp} 2.651 .705 .151$ & $\mathrm{Rp}$ & 22.666 .815 .473 & 0,1170 & \\
\hline & 2017 & $\mathrm{Rp} 2.663 .901 .421$ & $\mathrm{Rp}$ & 23.090.104.592 & 0,1154 & $2 \%$ \\
\hline \multirow[t]{2}{*}{ BSWD } & 2016 & $\begin{array}{ll}\mathrm{Rp} & 208.320 .000\end{array}$ & $\mathrm{Rp}$ & 3.197 .857 .544 & 0,0651 & \\
\hline & 2017 & Rp $\quad 274.712 .629$ & $\mathrm{Rp}$ & 3.366.092.766 & 0,0816 & $5 \%$ \\
\hline \multirow[t]{2}{*}{ INRU } & 2016 & Rp 4.530.425.800 & $\mathrm{Rp}$ & 2.385 .002 .920 & 1,8995 & \\
\hline & 2017 & $\mathrm{Rp} 4.551 .263 .070$ & $\mathrm{Rp}$ & 2.366.721.798 & 1,9230 & $(1 \%)$ \\
\hline \multirow[t]{2}{*}{ FIRE } & 2016 & $\begin{array}{ll}\mathrm{Rp} & 100.000 .000\end{array}$ & $\mathrm{Rp}$ & 253.848 .790 & 0,3939 & \\
\hline & 2017 & $\mathrm{Rp} \quad 130.344 .068$ & $\mathrm{Rp}$ & 232.927 .381 & 0,5596 & $(8 \%)$ \\
\hline \multirow[t]{2}{*}{ INDR } & 2016 & Rp 2.159.732.884 & $\mathrm{Rp}$ & 7.557.299.086 & 0,28578 & \\
\hline & 2017 & Rp 2.169.666.374 & $\mathrm{Rp}$ & 6.984 .997 .929 & 0,31062 & $(8 \%)$ \\
\hline \multirow[t]{2}{*}{ ATPK } & 2016 & Rp $\quad 659.145 .009$ & $\mathrm{Rp}$ & 848.700 .573 & 0,7767 & \\
\hline & 2017 & Rp $\quad 659.145 .008$ & $\mathrm{Rp}$ & 607.874 .994 & 1,0843 & $(28 \%)$ \\
\hline \multirow[t]{2}{*}{ CKRA } & 2016 & Rp 1.275.455.273 & $\mathrm{Rp}$ & 21.323 .170 & 59,8155 & \\
\hline & 2017 & $\mathrm{Rp} 1.275 .455 .273$ & $\mathrm{Rp}$ & 15.113.405 & 84,3923 & $(29 \%)$ \\
\hline \multirow[t]{2}{*}{ AISA } & 2016 & $\begin{array}{ll}\mathrm{Rp} & 684.220 .000\end{array}$ & $\mathrm{Rp}$ & 4.990 .139 .000 & 0,1371 & \\
\hline & 2017 & 684.220 .000 & $\mathrm{Rp}$ & 5.319 .855 .000 & 0,1286 & $7 \%$ \\
\hline \multirow[t]{2}{*}{ MDIA } & 2016 & 392.155 .384 & $\mathrm{Rp}$ & 754.380 .347 & 0,5198 & \\
\hline & 2017 & $\mathrm{Rp} \quad 392.155 .384$ & $\mathrm{Rp}$ & 2.495.163.449 & 0,1572 & $131 \%$ \\
\hline \multirow[t]{2}{*}{ SIAP } & 2016 & Rp 2.400.000.000 & $\mathrm{Rp}$ & 227.729 .847 & 10,5388 & \\
\hline & 2017 & $\mathrm{Rp} 2.400 .000 .000$ & $\mathrm{Rp}$ & 238.682 .417 & 10,0552 & $5 \%$ \\
\hline \multirow[t]{2}{*}{ AIMS } & 2016 & $\begin{array}{ll}\mathrm{Rp} & 11.000 .000\end{array}$ & $\mathrm{Rp}$ & 396.455 & 27,7459 & \\
\hline & 2017 & 11.000 .000 & $\mathrm{Rp}$ & 127.732 & 86,1177 & $(62 \%)$ \\
\hline
\end{tabular}

Sumber: Data diolah (2019).

Untuk keadaan modal kerja dan saldo laba PT Indonesia Prima Property, Tbk. mengalami penurunan kinerja, tetapi hal tersebut tidak membuat variabel $\mathrm{X}_{1}, \mathrm{X}_{2}$, dan $\mathrm{X}_{4}$ nilainya negatif melainkan bernilai positif. PT Golden Energy Mines, Tbk. berada dalam posisi sehat dengan nilai Z" di atas kategori nilai indikator yang berkinerja baik, karena modal kerja dan saldo laba meningkat meskipun total hutang juga meningkat. Hal tersebut terjadi bersamaan pula dengan meningkatnya total aktiva. Untuk keadaan saldo laba dan EBIT PT Golden Energy Mines, Tbk mengalami peningkatan kinerja, sehingga membuat semua variabel bernilai positif dari variabel $\mathrm{X}_{1}, \mathrm{X}_{2}, \mathrm{X}_{3}$, dan $\mathrm{X}_{4}$.

PT Cakra Mineral, Tbk. mendapatkan hasil nilai Z" di atas kategori nilai indikator yang menandakan bahwa perusahaan dalam posisi sehat walaupun total aktiva menurun. Namun, total hutang perusahaan ini menurun dan sempat mengalami hasil nilai variabel $\mathrm{X}_{3}$ negatif, karena EBIT bernilai negatif. Hal tersebut tidak berpengaruh terhadap kinerja perusahaan, karena perusahaan didukung nilai modal kerja meningkat. Untuk keadaan saldo laba PT Cakra Mineral, Tbk. mengalami stabil dan untuk variabel $\mathrm{X}_{1}, \mathrm{X}_{2}$, dan $\mathrm{X}_{4}$ bernilai positif. 
Tabel 6. Hasil Perhitungan Z"

\begin{tabular}{|c|c|c|c|c|c|c|c|}
\hline Kode & Tahun & $X_{1}$ & $\mathrm{X}_{2}$ & $\mathrm{X}_{3}$ & $\mathrm{X}_{4}$ & Z"' & Kriteria \\
\hline \multirow[t]{2}{*}{ OMRE } & 2016 & 0,0378 & 0,6910 & 0,0742 & 5,0694 & 8,3214 & Sehat \\
\hline & 2017 & 0,0216 & 0,6786 & $(0,0160)$ & 3,2547 & 5,6636 & Sehat \\
\hline \multirow[t]{2}{*}{ GEMS } & 2016 & 0,3959 & 0,0012 & 0,1441 & 0,5771 & 4,1754 & Sehat \\
\hline & 2017 & 0,2849 & 0,0009 & 0,2919 & 0,2182 & 4,0621 & Sehat \\
\hline \multirow[t]{2}{*}{ BORN } & 2016 & $(0,6400)$ & 0,1483 & 0,1977 & 0,1170 & $(2,2641)$ & Bangkrut \\
\hline & 2017 & $(0,5442)$ & 0,1396 & 0,0542 & 0,1154 & $(2,6294)$ & Bangkrut \\
\hline \multirow[t]{2}{*}{ BSWD } & 2016 & 0,1977 & 0,0046 & $(0.1911)$ & 0,0651 & 0,0966 & Bangkrut \\
\hline & 2017 & 0,1456 & 0,0045 & $(0.0732)$ & 0,0816 & 0,5636 & Bangkrut \\
\hline \multirow[t]{2}{*}{ INRU } & 2016 & $(0,0529)$ & $(1,5540)$ & $(0,0378)$ & 1,8995 & $(3,6727)$ & Bangkrut \\
\hline & 2017 & 0,0405 & $(1,5614)$ & 0,0057 & 1,9230 & $(2,7675)$ & Bangkrut \\
\hline \multirow[t]{2}{*}{ FIRE } & 2016 & 0,0136 & $(0,0450)$ & 0,0561 & 0,3939 & 0,7332 & Bangkrut \\
\hline & 2017 & 0,2876 & $(0,0352)$ & 0,0145 & 0,5596 & 2,4568 & Grey Area \\
\hline \multirow[t]{2}{*}{ INDR } & 2016 & 0,02789 & 0,00002 & 0,00754 & 0,28578 & 0,53375 & Bangkrut \\
\hline & 2017 & 0,01397 & 0,00002 & 0,01485 & 0,31062 & 0,51767 & Bangkrut \\
\hline \multirow[t]{2}{*}{ ATPK } & 2016 & $(0,0454)$ & $(0,3689)$ & $(0,1844)$ & 0,7767 & $(1,9235)$ & Bangkrut \\
\hline & 2017 & $(0,1739)$ & $(0,9169)$ & $(0,3095)$ & 1,0843 & $(5,0712)$ & Bangkrut \\
\hline \multirow[t]{2}{*}{ CKRA } & 2016 & 0,2406 & 0,0001 & $(0,0600)$ & 59,8155 & 63,9816 & Sehat \\
\hline & 2017 & 0,9783 & 0,0002 & $(0,4567)$ & 84,3923 & 91,9615 & Sehat \\
\hline \multirow[t]{2}{*}{ AISA } & 2016 & 0,3722 & 0,1941 & 0,0971 & 0,1371 & 3,8710 & Sehat \\
\hline & 2017 & 0,0727 & 0,1411 & $(0,1109)$ & 0,1286 & 0,3268 & Bangkrut \\
\hline \multirow[t]{2}{*}{ MDIA } & 2016 & 0,5284 & 0,0054 & 0,2615 & 0,5198 & 5,7870 & Sehat \\
\hline & 2017 & 0,6937 & 0,0041 & 0,1243 & 0,1572 & 5,5642 & Sehat \\
\hline \multirow[t]{2}{*}{ SIAP } & 2016 & $(0,1029)$ & $(0,4184)$ & $(0,1092)$ & 10,5388 & 8,2926 & Sehat \\
\hline & 2017 & $(0,1459)$ & $(0,4680)$ & $(0,0508)$ & 10,0552 & 7,7333 & Sehat \\
\hline \multirow[t]{2}{*}{ AIMS } & 2016 & 0,9787 & 0,0086 & $(0,1303)$ & 27,7459 & 34,7060 & Sehat \\
\hline & 2017 & 0,9915 & 0,0097 & $(0,1051)$ & 86,1177 & 96,2532 & Sehat \\
\hline
\end{tabular}

Sumber: Data diolah (2019).

Keterangan:

Skor Z" > 2,99 : perusahaan dalam kondisi sehat.

$1,81 \leq$ Skor Z" $\leq 2,99$ : perusahaan berada dalam grey area.

Skor Z" $<1,81 \quad$ : perusahaan berpotensi bangkrut.

Sumber: (Altman et al., 2010).

PT Intermedia Capital, Tbk. berada dalam posisi sehat, karena hasil nilai Z" di atas kategori nilai indikator dan semua hasil variabel $\mathrm{X}_{1}, \mathrm{X}_{2}, \mathrm{X}_{3}$, dan $\mathrm{X}_{4}$ bernilai positif. Total aktiva dan modal kerja perusahaan mengalami peningkatan, meskipun total hutang juga meningkat dan EBIT menurun, sedangkan keadaan saldo labanya mengalami peningkatan.

PT Sekawan Intipratama, Tbk. mendapatkan hasil negatif pada tiga variabel, yaitu $\mathrm{X}_{1}, \mathrm{X}_{2}$, dan $\mathrm{X}_{3}$, karena total aktiva bernilai negatif, total hutang meningkat, dan EBIT bernilai negatif. Namun, keadaan perusahaan berada dalam posisi sehat dengan nilai Z" di atas kategori nilai indikator dan modal kerja meningkat. Keadaan saldo laba perusahaan mengalami peningkatan, sehingga variabel $\mathrm{X}_{4}$ bernilai positif.

PT Akbar Indo Makmur Stimec, Tbk. mendapatkan hasil nilai Z" di atas kategori nilai indikator yang menandakan bahwa perusahaan dalam posisi sehat walaupun total aktiva dan total hutang menurun, dan perusahaan sempat mengalami hasil nilai variabel $\mathrm{X}_{3}$ negatif di kedua tahun, karena EBIT bernilai negatif. Keadaan modal kerja dan EBIT perusahaan mengalami penurunan kinerja, sedangkan saldo laba mengalami stabil, sedangkan tiga variabel lainnya, yaitu variabel $\mathrm{X}_{1}, \mathrm{X}_{2}$, dan $\mathrm{X}_{4}$ bernilai positif. 
Satu dari tujuh perusahaan yang sehat mengalami satu tahun dalam posisi sehat, yaitu di tahun pertama atau 2016, kemudian mengalami bangkrut pada tahun kedua atau 2017 yaitu PT Tiga Pilar Sejahtera Food, Tbk. Perusahaan ini mengalami nilai negatif pada variabel $\mathrm{X}_{3}$ di tahun 2017 dan mengalami penurunan kinerja pada total aktiva, modal kerja, EBIT, dan saldo laba, sedangkan total hutang mengalami peningkatan. Kinerja ini membuat hasil nilai Z" di bawah kategori nilai indikator pada tahun 2017, sedangkan pada tahun 2016, hasil nilai Z" di atas kategori nilai indikator. Nilai variabel $\mathrm{X}_{1}, \mathrm{X}_{2}$, dan $\mathrm{X}_{4}$ bernilai positif.

Perusahaan PT Alfa Energi Investama, Tbk. mengalami posisi grey area di tahun kedua atau tahun 2017, karena nilai Z" berada pada posisi antara bangkrut dan sehat, sedangkan di tahun pertama atau tahun 2016 nilai Z" di bawah kategori nilai indikator menyebabkan perusahaan berada dalam posisi bangkrut, karena hal tersebut disebabkan modal kerjanya mengalami peningkatan drastis, serta total aktiva meningkat meskipun EBIT dan total hutang menurun. Keadaan saldo laba perusahaan mengalami peningkatan, sedangkan nilai variabel $\mathrm{X}_{2}$ bernilai negatif disebabkan oleh saldo laba negatif dan tiga variabel lainnya bernilai positif, yaitu variabel $X_{1}, X_{3}$, dan $X_{4}$.

Perusahaan yang menghasilkan nilai Z" di bawah kategori nilai indikator dan menjadikan keadaan perusahaan dalam posisi bangkrut berjumlah tujuh perusahaan dari 13 perusahaan. Dari tujuh perusahaan tersebut ada lima perusahaan yang mengalami posisi bangkrut di kedua periode antara tahun 2016-2017, di antaranya adalah PT Borneo Lumbung Energi \& Metal, Tbk. menghasilkan nilai negatif pada hasil Z”, sehingga hasil tersebut berdampak pada keadaan perusahaan dalam posisi bangkrut. Variabel $\mathrm{X}_{1}$ juga menghasilkan nilai negatif, serta modal kerja dan EBIT menurun, sedangkan saldo laba dalam posisi stabil. Keadaan total aktiva dan total hutang perusahaan mengalami peningkatan dan variabel $\mathrm{X}_{2}, \mathrm{X}_{3}$, dan $\mathrm{X}_{4}$ bernilai positif.

PT Bank of India Indonesia, Tbk. menghasilkan nilai Z" di bawah kategori nilai indikator dan hasil negatif dari variabel $\mathrm{X}_{3}$. Hal tersebut dikarenakan EBIT bernilai negatif. Penurunan kinerja dialami oleh perusahaan ini, yaitu penurunan pada modal kerja, sedangkan total hutang meningkat. Di sisi lain, perusahaan mengalami peningkatan pada total aktiva. Keadaan saldo laba PT Bank of India Indonesia, Tbk. mengalami stabil dan untuk 3 variabel lainnya bernilai positif, yaitu variabel $\mathrm{X}_{1}, \mathrm{X}_{2}$, dan $\mathrm{X}_{4}$.

PT Toba Pulp Lestari, Tbk. mendapatkan nilai Z" negatif, sehingga indikasi ini menunjukkan bahwa perusahaan dalam posisi bangkrut, karena $X_{2}$ bernilai negatif di kedua tahun, serta $X_{1}$ dan $X_{3}$ bernilai negatif pada tahun 2016. Namun, modal kerja dan total hutang perusahaan mengalami penurunan, walaupun total aktiva dan saldo laba tidak bergerak atau stabil. Variabel $\mathrm{X}_{4}$ perusahaan ini menghasilkan nilai positif.

PT Indo-Rama Synthetics, Tbk. menghasilkan nilai positif di semua variabel, yaitu $\mathrm{X}_{1}, \mathrm{X}_{2}, \mathrm{X}_{3}$, dan $\mathrm{X}_{4}$. Namun, hal tersebut tidak membuat keadaan perusahaan dalam posisi sehat, karena nilai Z" berada di bawah kategori nilai indikator, serta perusahaan mengalami penurunan pada modal kerja dan total aktiva. Meskipun total hutang mengalami penurunan, tetapi EBIT dan saldo laba meningkat. Hasil ini membuat keadaan perusahaan berada pada posisi bangkrut.

PT Bara Jaya Internasional, Tbk. mengalami penurunan total aktiva yang disebabkan oleh aktiva lancar dan aktiva tetap mengalami penurunan dan menghasilkan nilai variabel $X_{1}, X_{2}$, dan $X_{3}$ bernilai negatif, sehingga hasil Z" bernilai negatif, tetapi modal 
kerja meningkat dan total hutang menurun. Perusahaan tetap berada dalam posisi bangkrut. Saldo laba dan EBIT perusahaan ini meningkata dan variabel yang tersisa, yaitu variabel $\mathrm{X}_{4}$ menghasilkan nilai positif. Rangkuman hasil analisis tersebut dapat dilihat pada Tabel 7 berikut ini.

Tabel 7. Rangkuman Hasil Analisis

\begin{tabular}{|c|c|}
\hline \multicolumn{2}{|c|}{ PT Indonesia Prima Property, Tbk. } \\
\hline Posisi Sehat & Kinerja Baik \\
\hline \multicolumn{2}{|c|}{ PT Golden Energy Mines, Tbk. } \\
\hline Posisi Sehat & Kinerja Baik \\
\hline \multicolumn{2}{|c|}{ PT Borneo Lumbung Energi \& Metal, Tbk. } \\
\hline Posisi Bangkrut & Kinerja Kurang Baik \\
\hline \multicolumn{2}{|c|}{ PT Bank of India Indonesia, Tbk. } \\
\hline Posisi Bangkrut & Kinerja Baik \\
\hline \multicolumn{2}{|c|}{ PT Toba Pulp Lestari, Tbk. } \\
\hline Posisi Bangkrut & Kinerja Baik \\
\hline \multicolumn{2}{|c|}{ PT Alfa Energi Investama, Tbk. } \\
\hline Posisi Bangkrut-Grey Area & Kinerja Baik \\
\hline \multicolumn{2}{|c|}{ PT Indo-Rama Synthetics, Tbk. } \\
\hline Posisi Bangkrut & Kinerja Baik \\
\hline \multicolumn{2}{|c|}{ PT Bara Jaya Internasional, Tbk. } \\
\hline Posisi Bangkrut & Kinerja Baik \\
\hline \multicolumn{2}{|c|}{$\begin{array}{l}\text { PT Cakra Mineral, Tbk. } \\
\end{array}$} \\
\hline Posisi Sehat & Kinerja Baik \\
\hline \multicolumn{2}{|c|}{$\begin{array}{l}\text { PT Tiga Pilar Sejahtera Food, Tbk. } \\
\end{array}$} \\
\hline Posisi Sehat-Bangkrut & Kinerja Baik \\
\hline \multicolumn{2}{|c|}{ PT Intermedia Capital, Tbk. } \\
\hline Posisi Sehat & Kinerja Baik \\
\hline \multicolumn{2}{|c|}{ PT Sekawan Intipratama, Tbk. } \\
\hline Posisi Sehat & Kinerja Baik \\
\hline \multicolumn{2}{|c|}{ PT Akbar Indo Makmur Stimec, Tbk. } \\
\hline Posisi Sehat & Kinerja Baik \\
\hline
\end{tabular}

Sumber: Data diolah (2019).

\section{KESIMPULAN DAN SARAN}

Berdasarkan hasil analisis dan pembahasan di atas, maka peneliti menyimpulkan bahwa perusahaan yang berada dalam posisi sehat di kedua periode antara tahun 20162017 adalah PT Indonesia Prima Property, Tbk.; PT Golden Energy Mines, Tbk.; PT Cakra Mineral, Tbk.; PT Intermedia Capital, Tbk.; PT Sekawan Intipratama, Tbk.; dan PT Akbar Indo Makmur Stimec, Tbk. dengan kinerja baik.

Perusahaan yang berada dalam posisi bangkrut di kedua periode antara tahun 2016-2017 adalah PT Borneo Lumbung Energi \& Metal, Tbk. dengan kinerja kurang baik; sedangkan PT Bank of India Indonesia, Tbk.; PT Toba Pulp Lestari, Tbk.; PT Indo-Rama Synthetics, Tbk.; dan PT Bara Jaya Internasional, Tbk dengan keadaan berkinerja baik.

Dua perusahaan lainnya, yaitu PT Tiga Pilar Sejahtera Food, Tbk. berada dalam posisi sehat pada tahun 2016 dan bangkrut pada tahun 2017 dengan kinerja baik, sedangkan PT Alfa Energi Investama, Tbk. berada dalam posisi bangkrut di tahun 2016 dan posisi grey area di tahun 2017 dengan keadaan berkinerja baik pula. 
Perusahaan yang berada dalam posisi grey area atau bahkan sudah dalam posisi bangkrut, tetapi kinerja perusahaan dalam keadaan baik karena total aktiva masih mampu memenuhi total hutang, maka perusahaan tersebut tidak terlilit hutang dan masih bisa diselamatkan. Hal tersebut dilakukan dengan meningkatkan kinerja perusahaan lebih tinggi agar hutang dapat tertutup dengan baik. Dari hasil pembahasan di atas, ada satu perusahaan yang benar-benar mengkhawatirkan, yaitu PT Borneo Lumbung Energi \& Metal, Tbk., karena posisi perusahaan bangkrut dan kinerja perusahaan dalam keadaan kurang baik. Perusahaan ini patut menjadi sorotan utama dalam peningkatan kinerjanya.

Untuk perusahaan yang berada dalam posisi sehat dan berkinerja baik, tidak menutup kemungkinan dapat menurunkan posisi dan kinerjanya, apabila perusahaan, khususnya pihak manajemen bertindak lengah atas kinerjanya. Perusahaan dapat mempertahankan atau bahkan menaikkan kinerjanya agar posisi dan keadaan perusahaan tidak mengalami penurunan.

Hasil analisis menunjukkan bahwa beberapa perusahaan mengalami kebangkrutan, tetapi hal tersebut tidak menjamin perusahaan benar-benar mengalami kebangkrutan. Perusahaan yang berada dalam masa suspensi tidak bisa diartikan bahwa kinerja keuangannya pasti buruk. Demikian pula, tidak semua perusahaan yang delisting dari Bursa Efek Indonesia benar-benar mengalami kebangkrutan. Tindakan penghapusan saham dari daftar saham yang diperdagangkan atau suspensi dapat dilakukan atas permintaan perusahaan sendiri atau benar-benar dikeluarkan oleh BEI karena alasan kesulitan keuangan. Kebangkrutan dapat menjadi salah satu penyebab perusahaan berada dalam masa suspensi atau bahkan mengalami delisting oleh BEI.

Berdasarkan hasil penelitian ini, peneliti menyarankan pihak manajemen perusahaan untuk fokus dalam meningkatkan kinerja perusahaan, khususnya pada modal kerja dan saldo laba yang diperoleh agar perusahaan mampu bertahan dan saham perusahaan dapat dibebaskan dari sanksi suspensi, sehingga perdagangan sahamnya tetap dapat dilakukan di Bursa Efek Indonesia.

\section{DAFTAR REFERENSI}

Altman, E. I. (2007). Financial Ratios, Discriminant Analysis and the Prediction of Corporate Bankruptcy. The Journal of Finance, 23(4), 589-609.

Altman, E. I., Danovi, A., \& Falini, A. (2010). Z-Score Models' Application to Italian Companies Subject to Extraordinary Administration. Journal of Applied Finance, 2(2), 1-10.

Altman, E. I., Hartzell, J., \& Peck, M. (1995). Emerging Markets Corporate Bonds: A Scoring System. New York: Salomon Brothers, Inc. Revisited in Altman, E. I. \& Hotchkiss, E. (2006). Corporate Financial Distress \& Bankruptcy. New York: John Wiley \& Sons, Inc.

Bahri, S. (2015). Analisis Prediksi Kebangkrutan pada Perusahaan yang di Delisting di Bursa Efek Indonesia. Jurnal Ilmu dan Riset Manajemen, 4(8), 1-22.

Fitri, S. A. (2016). Pengaruh Kinerja Keuangan Terhadap Harga Saham Perusahaan Food and Beverages di BEI. Jurnal Ilmu dan Riset Manajemen, 5(April), 1-16. 
Gere, M. F. (2015). Pengaruh Kinerja Keuangan Terhadap Harga Saham Perusahaan Manufaktur di Bursa Efek Indonesia. Jurnal Ilmu dan Riset Manajemen, 4(8), 117.

Gupta, A. T., \& Suartana, I. W. (2018). Pengaruh Financial Distress dan Kualitas Corporate Governance pada Manajemen Laba. E-Jurnal Akuntansi Universitas Udayana, 23(2), 26. https://doi.org/10.24843/EJA.2018.v23.i02.p26.

Lakhaye, A. (2014). Analisis Faktor Penyebab Involuntary Delisting Perusahaan di Indonesia. Jurnal Akuntansi UNESA, 3(1), 1-23.

Paradiba, L., \& Nainggolan, K. (2015). Pengaruh Laba Bersih Operasi Terhadap Harga Saham pada Perusahaan Food and Beverages yang Terdaftar di BEI. Jurnal Riset Akuntansi dan Bisnis, 15(1), 113-124.

Permana, R. K., Ahmar, N., \& Djadang, S. (2017). Prediksi Financial Distress pada Perusahaan Manufaktur di Bursa Efek Indonesia. Esensi: Jurnal Bisnis dan Manajemen, 7(2), 149-166. https://doi.org/10.15408/ess.v7i2.4797.

Puspitaningrum, T., \& Purnamasari, L. (2016). Analisis Prediktor Delisting Terbaik (Perbandingan Antara Model Zmijewski, Model Altman, Model Springate). Buletin Studi Ekonomi, 21(1), 38-47.

Safitri, A. R., Nurdin, \& Bayumi, E. M. (2018). Analisis Kebangkrutan Perusahaan pada Saham Syariah yang Mengalami Suspensi di Bursa Efek Indonesia dengan Menggunakan Metode Altman Z-Score. Prosiding Keuangan dan Perbankan Syariah, 4(1), 264-269.

Sanusi, A. (2011). Metodologi Penelitian Bisnis. Jakarta: Salemba Empat.

Savitri, D. W. (2014). Analisis Prediktor Kebangkrutan Terbaik dengan Menggunakan Metode Altman, Springate, dan Zmijewski pada Perusahaan Delisting dari Bursa Efek Indonesia Tahun 2012 (Studi Laporan Keuangan Tahun 2007-2011). eProceedings of Management, 1(3), 1-10.

Sembiring, E. E. (2016). Analisis Keakuratan Model Ohlson dalam Memprediksi Kebangkrutan (Delisting) Perusahaan yang terdaftar di BEI. Jurnal Akuntansi Keuangan dan Bisnis, 9(November), 1-9.

Sugiyono (2014). Metode Penelitian Bisnis. Bandung: Alfabeta.

Syafitri, L. (2013). Analisis Komparatif dalam Memprediksi Kebangkrutan pada PT Indofood Sukses Makmur, Tbk. Jurnal Akuntansi dan Keuangan, 16(2), 1-14.

Vestari, M., \& Farida, D. N. (2017). Analisis Rasio-Rasio dan Ukuran Keuangan, Prediksi Financial Distress, dan Reaksi Investor. AKRUAL: Jurnal Akuntansi, 5(1), 26-44. https://doi.org/10.26740/jaj.v5n1. 